\title{
th. 163.4 \\ ORNL/TM-6159
}

\section{MSSTER}

\section{Corrosivity of Geothermal Brines Progress Report for Period Ending June 1977}

\author{
F. A. Posey \\ A. A. Palko \\ A. L. Bacarella
}




\section{DISCLAIMER}

This report was prepared as an account of work sponsored by an agency of the United States Government. Neither the United States Government nor any agency Thereof, nor any of their employees, makes any warranty, express or implied, or assumes any legal liability or responsibility for the accuracy, completeness, or usefulness of any information, apparatus, product, or process disclosed, or represents that its use would not infringe privately owned rights. Reference herein to any specific commercial product, process, or service by trade name, trademark, manufacturer, or otherwise does not necessarily constitute or imply its endorsement, recommendation, or favoring by the United States Government or any agency thereof. The views and opinions of authors expressed herein do not necessarily state or reflect those of the United States Government or any agency thereof. 


\section{DISCLAIMER}

Portions of this document may be illegible in electronic image products. Images are produced from the best available original document. 
Printed in the United States of America. Available from National Technical Information Service

U.S. Department of Commerce

5285 Port Royal Road, Springfield, Virginia 22161

Price: Printed Copy $\$ 4.50$, Microfiche $\$ 3.00$

$$
\text { 4. } 4
$$

This report was prepared as an account of work sponsored by an agency of the United States Government. Neither the United States. Government nor any agency thereof, nor any of their employees, contractors, subcontractors, or their employees, makes any warranty, express or implied, nor assumes any legal liability or responsibility for any third party's use or the results of such use of any information, apparatus, product or process disclosed in this report, nor represents that its use by such third party would not infringe privately owned rights. 
ORNL/TM-6159

Dist. Category UC-4

\author{
Contract No. W-7405-eng-26 \\ CHEMISTRY DIVISION
}

\begin{abstract}
CORROSIVITY OF GEOTHERMAL BRINES
PROGRESS REPORT FOR PERIOD ENDING JUNE 1977
\end{abstract}

F. A. Posey, A. A. Palko, and A. L. Bacarella

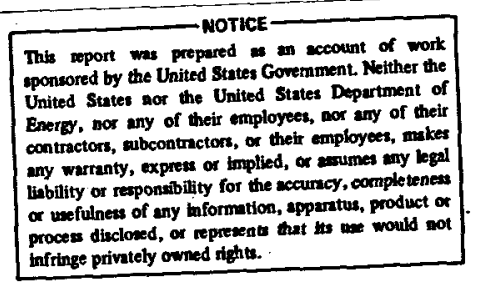

Date Published - November 1977

NOTICE This document contains information of a preliminary nature. It is subject to revision or correction and therefore does not represent a final report.

\author{
OAK RIDGE NATIONAL LABORATORY \\ Oak Ridge, Tennessee 37830 \\ operated by \\ UNION CARBIDE CORPORATION \\ for the \\ DEPARTMENT OF ENERGY
}




\section{CONTENTS}

$\underline{\text { Page }}$

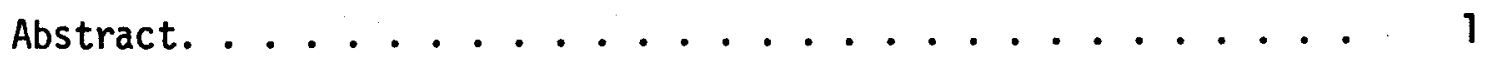

Introduction. ......................... 1

Effect of $\mathrm{pH}$ and Temperature on the Corrosion Rate of A212B

Carbon Steel in Deaerated $4 \mathrm{M} \mathrm{NaCl} \ldots \ldots$

Influence of Temperature on Pitting of Types 304 and 316

Stainless Steel in $4 \mathrm{M} \mathrm{NaCl} \ldots \ldots 13$

Research Plans for the Forthcoming Period . . . . . . . 17

References....................... 19 
CORROSIVITY OF GEOTHERMAL BRINES

PROGRESS REPORT FOR PERIOD ENDING JUNE 1977

F. A. Posey, A. A. Palko, and A. L. Bacarella

ABSTRACT

Studies carried out during FY 1977 on the corrosivity of ferrous materials in synthetic geothermal brines are described. The effect of $\mathrm{pH}$ (from $\mathrm{pH}=7$ to $\mathrm{pH}=2$ ) and temperature (from $25^{\circ}$ to $200^{\circ} \mathrm{C}$ ) on the corrosion rate of type A212B carbon steel in deaerated $4 \mathrm{M} \mathrm{NaCl}$ is described. The data were obtained by use of a refreshed, stirred titanium autoclave system for making electrochemical measurements up to at least $200^{\circ} \mathrm{C}$. A relatively simple numerical correlation describes the data over the entire temperature and $\mathrm{pH}$ range. The spontaneous corrosion potentials and pitting potentials of types 304 and 316 stainless steel were measured in deaerated $4 \mathrm{M} \mathrm{NaCl}$ at $\mathrm{pH}=5$ from $25^{\circ}$ to $200^{\circ}$, and the data demonstrate the borderline stability of austenitic stainless steel for brine service. Plans for conclusion of the research during the remainder of FY 1977 are presented.

\section{INTRODUCTION}

This report presents results of continuing studies on the corrosion of ferrous materials in synthetic geothermal brines. Previous reports ${ }^{1,2}$ contain results of studies carried out principally during 1976. As stated earlier, the purpose of these investigations, which are sponsored by the Division of Geothermal Energy of the U. S. Energy Research and Development Administration, is to develop a basic understanding of corrosion processes of ferrous materials such as iron and carbon steel in geothermal brines. A quantitative knowledge of the kinetics of corrosion processes in synthetic geothermal brines and the influence of such variables as solution composition and temperature on them can be expected to provide a scientific basis for interpretation of field corrosion tests, on-line corrosion 
measurements, and plant corrosion experience, and perhaps suggest rational means for control or mitigation of corrosion during various stages of geothermal plant operation.

In a previous report ${ }^{1}$ results of some electrochemical measurements were presented on the spontaneous corrosion potentials and corrosion rates, and on the kinetics of the anodic and cathodic corrosion reactions of iron and carbon steel in $4 \mathrm{M} \mathrm{NaCl}$ solution over the $\mathrm{pH}$ range from 1 to 11 at temperatures up to $85^{\circ} \mathrm{C}$ in a conventional Pyrex electrochemical cell. In addition, a refreshed, stirred titanium autoclave system was designed, constructed, and tested; this assembly was designed to permit electrochemical measurements to be made up to at least $200^{\circ} \mathrm{C}$ in corrosive aqueous sal ine media. The effect of $\mathrm{pH}$ on hydrolysis, precipitation, and electrochemical reactivity of ferrous and ferric ions in $4 \underline{\mathrm{M} \mathrm{NaCl}}$ at $25^{\circ} \mathrm{C}$ was studied, and implications for plant operation were discussed. In addition, the pitting potential of type 304 stainless steel in deaerated synthetic brine was measured as a function of temperature from $25^{\circ}$ to $85^{\circ} \mathrm{C}$.

In a later report ${ }^{2}$ results were presented on the polarization behavior and corrosion rate of carbon steel in $4 \underline{\mathrm{M} \mathrm{NaCl}}, \mathrm{pH}=5$ (at room temperature), all the way from room temperature up to $200^{\circ} \mathrm{C}$. Also discussed were several modifications to the reference and test electrode assemblies of the refreshed, stirred titanium autoclave system which were required as the experiments progressed. Precautions which must be observed with respect to the choice of sweep rate and other aspects of the use of the potentiodynamic method for measurement of polarization curves and for estimation of corrosion rates by measurement of polarization resistance were discussed in some detail. In addition, the effect of chloride ion concentration on corrosion of iron at room temperature, $\mathrm{pH}=5$, was described. 
The observations presented here represent further progress towards the establishment of a baseline of data on the corrosion behavior of carbon steel in concentrated sodium chloride solutions. As noted earlier, ${ }^{2}$ data on electrochemical aspects of the corrosion of ferrous materials under geothermal conditions, whether real or simulated, are virtually nonexistent, and nearly al1 reported electrochemical work on ferrous materials in concentrated chloride solutions has so far been restricted to iroom temperature, During this period we have completed measurements on the polarization behavior and corrosion rate of carbon steel in $4 \mathrm{M} \mathrm{NaCl}$ at $\mathrm{pH}=2,3,4,5$, and 7 (measured at room temperature), all the way from room temperature up to at least $200^{\circ} \mathrm{C}$. These results are presented and discussed below along with a numerical correlation which describes the results over the entire range of temperature and $\mathrm{pH}$. Additionally, the results of measurement of the spontaneous corrosion potentials and the pitting potentials of types 304 and 316 stainless steel in $4 \mathrm{M} \mathrm{NaCl}$ from $25^{\circ}$ to $200^{\circ} \mathrm{C}$ are discussed. Finally, plans for conclusion of the research during the forthcoming period are presented.

EFFECT OF PH AND TEMPERATURE ON THE CORROSION RATE OF A212B CARBON STEEL IN DEAERATED 4 M NaCl

During this period a long series of experiments was completed in the refreshed, stirred titanium autoclave system on the effect of temperature (from $25^{\circ}$ to $200^{\circ} \mathrm{C}$ ) and $\mathrm{pH}$ (from $\mathrm{pH}=7$ to $\mathrm{pH}=2$ ) on the polarization behavior and spontaneous corrosion rate of type A212B carbon steel (a typical pipeline steel) in deaerated $4 \mathrm{M} \mathrm{NaCl}$. The minor constituents of this carbon steel, as determined by analysis, were present in the following percentages: $0.358 \% \mathrm{C}, 0.62 \% \mathrm{Mn}, 0.18 \% \mathrm{Si}, 0.033 \% \mathrm{~S}$, and $0.012 \% \mathrm{P}$. Some 
earlier results obtained in the same medium at $\mathrm{pH}=5$ were presented in a previous progress report, ${ }^{2}$ where it was noted that under these conditions the corrosion rate varied with temperature according to the expected Arrhenius-type law with an apparent activation energy of approximately 7.7 $\mathrm{kcal} / \mathrm{mole}$. The new data extend the earlier results over a wide range of temperature and $\mathrm{pH}$, and show the magnitude of the corrosion rates to be expected for corrosion of carbon steel in strong brines under deaerated conditions in the absence of significant amounts of oxidizable, reducible, and/or adsorbable substances (other than-chloride ions).

The measurements were carried out in a refreshed, stirred titanium autoclave system. A schematic diagram of the system is shown in Fig. 1. The stock solution (approx. 50 liters) of synthetic brine to be injected into the autoclave assembly was partially deaerated by sparging with argon. This solution was then pumped to the top of a deaeration column (length $\sim 120 \mathrm{~cm}$ ) and back to the reservoir so that the column was kept full. Solution entering the autoclave descended through the deaeration column, countercurrent to a stream of fine argon bubbles, before a diaphragm pulse pump (capacity $\sim 11$ iter/hr) forced it into the autoclave. A pressure gauge and a 1000 psi safety relief valve (rupture disk) were located between the pump and the autoclave. The temperature of the autoclave was controlled by a surrounding furnace which was regulated by an automatic temperature controller; the temperature inside the autoclave was monitored on a digital temperature indicator. Since the autoclave was constructed from titanium, it was possible to use a conventional Teflon-covered magnetic stirring bar inside the autoclave for stirring of the solution. Pressure inside the autoclave was maintained at any desired level (typically $200-500 \mathrm{psig}$ ) by a pneumatic letdown valve; the 


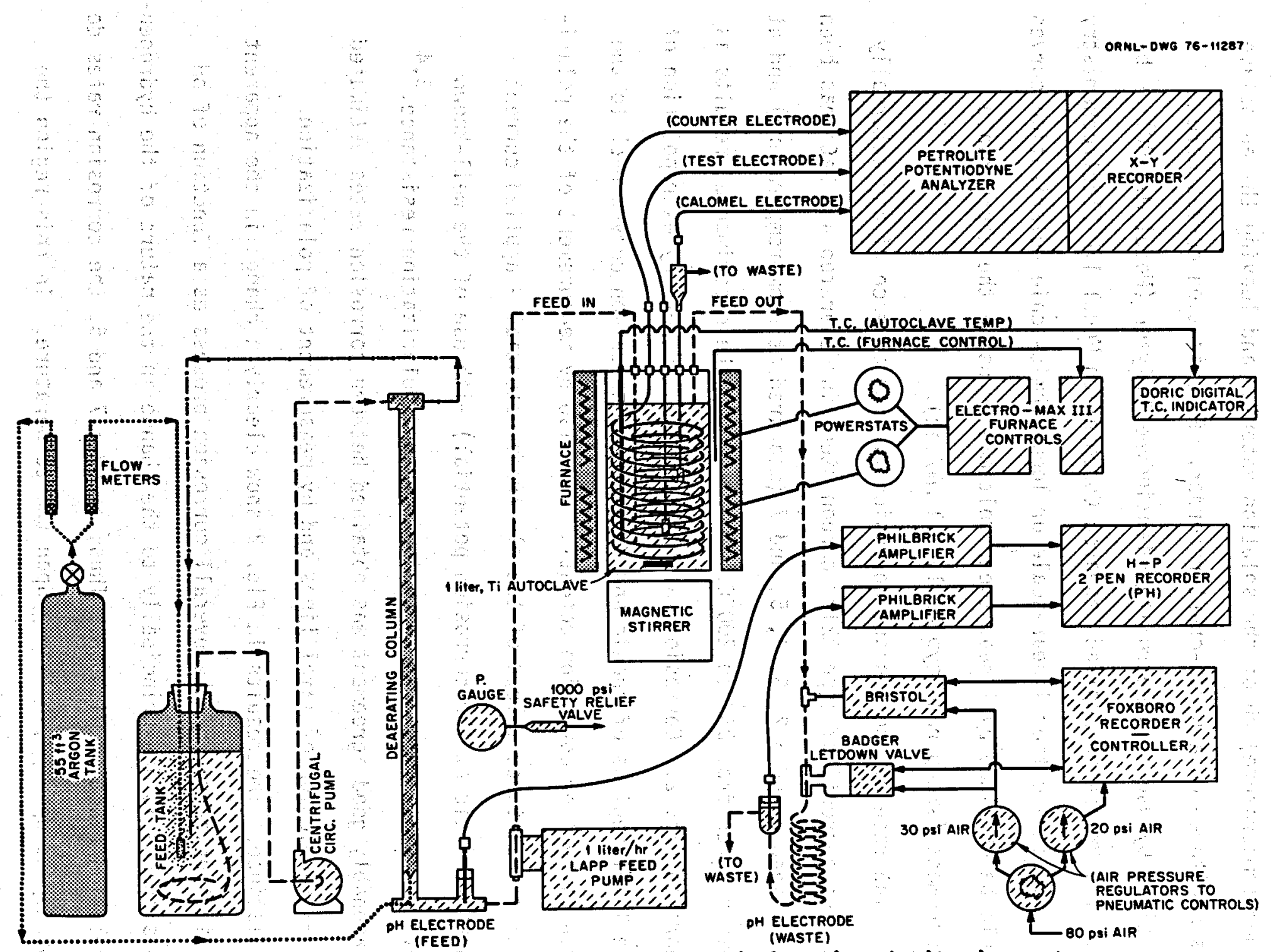

Fig. 1. Schematic diagram of refreshed, stirred titanium autoclave system for electrochemical studies. 
pressure was recorded continuously on a small strip-chart recorder. The (room-temperature) $\mathrm{pH}$ of the solution entering and leaving the autoclave was monitored on a strip-chart recorder. Polarization curves were obtained by use of a Petrolite Potentiodyne Analyzer (Model M-4100) or by use of a Princeton Applied Research Corporation Model 170 Electrochemistry System. Thus either linear-scale or logarithmic-scale polarization curves could be obtained by linear-sweep voltammetry using the appropriate instrument (sweep rate typically $0.1 \mathrm{mV} / \mathrm{sec}$ ).

The rate of spontaneous corrosion (in the absence of any externally applied current) of type $\mathrm{A212B}$ carbon steel in deaerated $4 \mathrm{M} \mathrm{NaCl}$ has been determined at $\mathrm{pH}=2,3,4,5$, and 7 (measured at room temperature) and at temperatures from $25^{\circ}$ to $200^{\circ} \mathrm{C}$. A summary of the experimental results is shown in Fig. 2. Corrosion rates were estimated both by extrapolation of the Tafel regions of anodic and cathodic polarization curves back to the open-circuit or corrosion potential and also by measurement of the polarization resistance (slope of the electrode potential - applied current characteristic at the corrosion potential) with use of the we11-known inverse relation between corrosion rate and polarization resistance. ${ }^{3,4}$ Reasonably good agreement was obtained between corrosion rates estimated by extrapolation of Tafel lines and by measurement of polarization resistance. The results in Fig. 2 show clearly a change in the apparent activation energy of the overall corrosion process as a function of $\mathrm{pH}$. This change is due principally to the change in the nature of the hydrogenevolution reaction with $\mathrm{pH}$. Thus, at $\mathrm{pH}=7$ and 5 , the corrosion rates do not depend upon $\mathrm{pH}$, but only upon the temperature. In this region the cathodic process consists mainly of hydrogen evolution from the solvent water. The apparent activation energy of the overall corrosion process in 
ORNL-DWG. $77-12066$

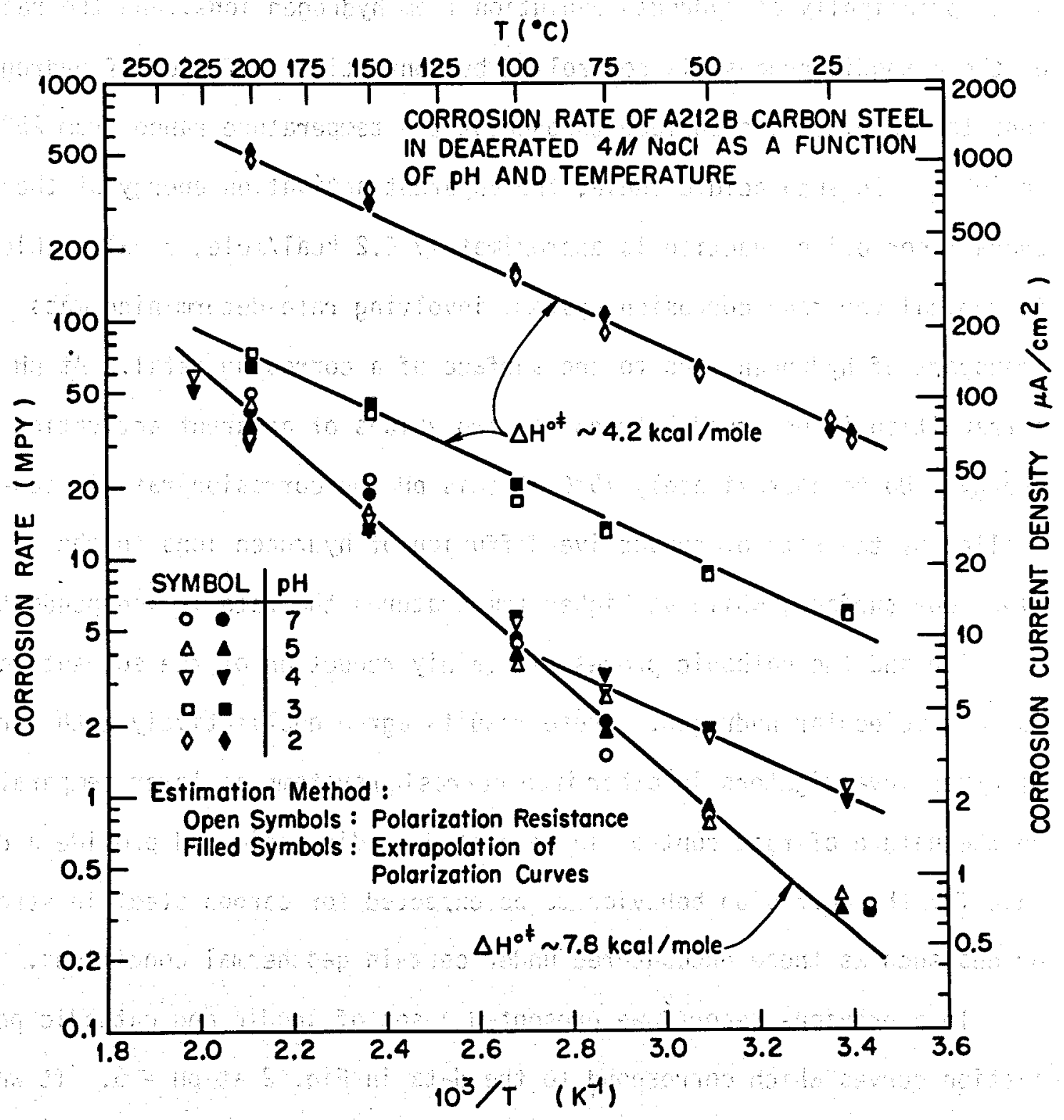

Fig. 2. Corrosion rate of $A 212 B$ carbon steel in deaerated $4 \underline{M}$ $\mathrm{NaCl}$ as a function of $\mathrm{pH}$ and temperature. 
this neutral $\mathrm{pH}$ range is approximately $7.8 \mathrm{kcal} / \mathrm{mole}$. On the other hand, in moderately acidic solutions at $\mathrm{pH}=3$ and 2 , the cathodic process consists principally of hydrogen evolution from hydrogen ions, and the rate of the cathodic process is controlled by convective diffusion of hydrogen ions to the electrode surface throughout the temperature range from $25^{\circ}$ to $200^{\circ} \mathrm{C}$. In such acidic media, the apparent activation energy of the overall corrosion reaction is approximately $4.2 \mathrm{kcal} / \mathrm{mole}$, a value which is typical for many corrosion systems involving rate-determining mass transport of hydrogen ions to the surface of a corroding metal. At $\mathrm{pH}=4$ a transition is observed between the two values of apparent activation energy. Up to approximately $75^{\circ} \mathrm{C}$ at this $\mathrm{pH}$ the corrosion rate is controlled by the rate of convective diffusion of hydrogen ions to the electrode surface, while at higher temperatures the rate is independent of stirring and the cathodic process is mainly reduction of the solvent water to form molecular hydrogen. These results agree qualitatively with work of other investigators in other iron corrosion systems at lower temperatures on the nature of rate control in deaerated acidic media and provide a data base for the corrosion behavior to be expected for carbon steel in strong brines such as those encountered under certain geothermal conditions.

In a previous report ${ }^{2}$ we presented a set of anodic and cathodic polarization curves which correspond to the data in Fig. 2 at $\mathrm{pH}=5$. It was believed at the time that the degree of stirring inside the titanium autoclave was sufficient to provide vigorous convection of the electrolyte since the observed cathodic polarization curves gave a slight indication of what was thought to be a limiting current for convective diffusion of hydrogen ions to the electrode surface. However, our subsequent measurements at lower $\mathrm{pH}$ have shown that this is not the case. The magnitudes of 
the limiting currents observed on cathodic polarization curves obtained at $\mathrm{pH}=3$ and 2 show clearly that stirring within the autoclave was not very efficient and that consequently convective diffusion of hydrogen ions to the electrode surface could not be responsible for the nature of the cathodic polarization curves which were observed in the neutral region at all temperatures. Subsequently, various computations have suggested that the change in slope of the cathodic polarization curves pertaining to the hydrogen-evolution reaction in the neutral region is caused by the accumulation of alkalinity in the vicinity of the electrode surface which accompanies the hydrogen-evolution reaction in unbuffered solutions. The $\mathrm{pH}$ at the interface under cathodic polarization in unbuffered solution is greater than the $\mathrm{pH}$ in the bulk of the solution, and the magnitude of the difference depends upon the rate of convective diffusion of hydroxide ions away from the electrode surface, and thus upon the stirring efficiency of the experimental arrangement. Since the Tafel slope of the cathodic polarization curve on iron in alkaline brine solutions is less than that for neutral or acidic solutions, it is possible to observe a change in the slope of the cathodic polarization curve under these conditions.

The data shown in Fig. 2 are described by a numerical correlation which has a basis in mechanistic considerations. Under the prevailing experimental conditions of non-vigorous stirring the corrosion rate in the acidic region is controlled, as noted above, by the maximum or limiting rate of convective diffusion of hydrogen ions to the electrode surface. Therefore the corrosion rate in this region depends directly upon the hydrogen ion activity (or concentration, approximately), and also upon the temperature since this influences the rate of convective diffusion. However, in the neutral region the rates of both the iron-dissolution reaction 
and the hydrogen-evolution reaction are essentially independent of $\mathrm{pH}$ as well as independent of stirring, as shown by the appropriate polarization curves. ${ }^{1}$ Consequently the rate of the overall corrosion reaction is also independent of $\mathrm{pH}$ in this region and depends only on the temperature since this influences the rates of both the anodic and the cathodic partial processes. A kinetic treatment of the problem which takes into account the kinetics of the partial processes in the two different $\mathrm{pH}$ regions leads to a relatively simple two-term expression for the corrosion rate:

$$
\begin{aligned}
i_{\text {corr }}= & 1.90 \times 10^{5} \exp \left(-3.98 \times 10^{3} / \mathrm{T}\right) \\
& +4.19 \times 10^{6}\left(10^{-\mathrm{pH}}\right) \exp \left(-2.10 \times 10^{3} / \mathrm{T}\right)
\end{aligned}
$$

Here, $i_{\text {corr }}$ is the corrosion rate in mils per year (mpy), $T$ is absolute temperature $\left({ }^{\circ} \mathrm{K}\right)$, and the numerical constants were computed from the lines drawn through the data in Fig. 2 at $\mathrm{pH}=2$ and at $\mathrm{pH}=7$ (or 5). The experimental data are shown in Fig. 3 replotted as corrosion rate vs. $\mathrm{pH}$ for several temperatures. The solid lines in Fig. 3 were calculated by use of Eq. (1). It is evident that, considering the experimental errors which typically accompany work of this type, the data are described reasonably well by the two-term expression of Eq. (1) over the entire temperature and $\mathrm{pH}$ range.

The $\mathrm{pH}$ term appearing in Eq. (1) refers to the $\mathrm{pH}$ as measured conventionally at room temperature (approximately $25^{\circ} \mathrm{C}$ ). There seems to be no absolute means of evaluating the hydrogen ion activity at elevated temperatures relative to the hydrogen ion activity at room temperature without recourse to nonthermodynamic assumptions, and some part of the temperature dependence of the corrosion rates observed at $\mathrm{pH}=2$ and 3 (and at $\mathrm{pH}=4$ 


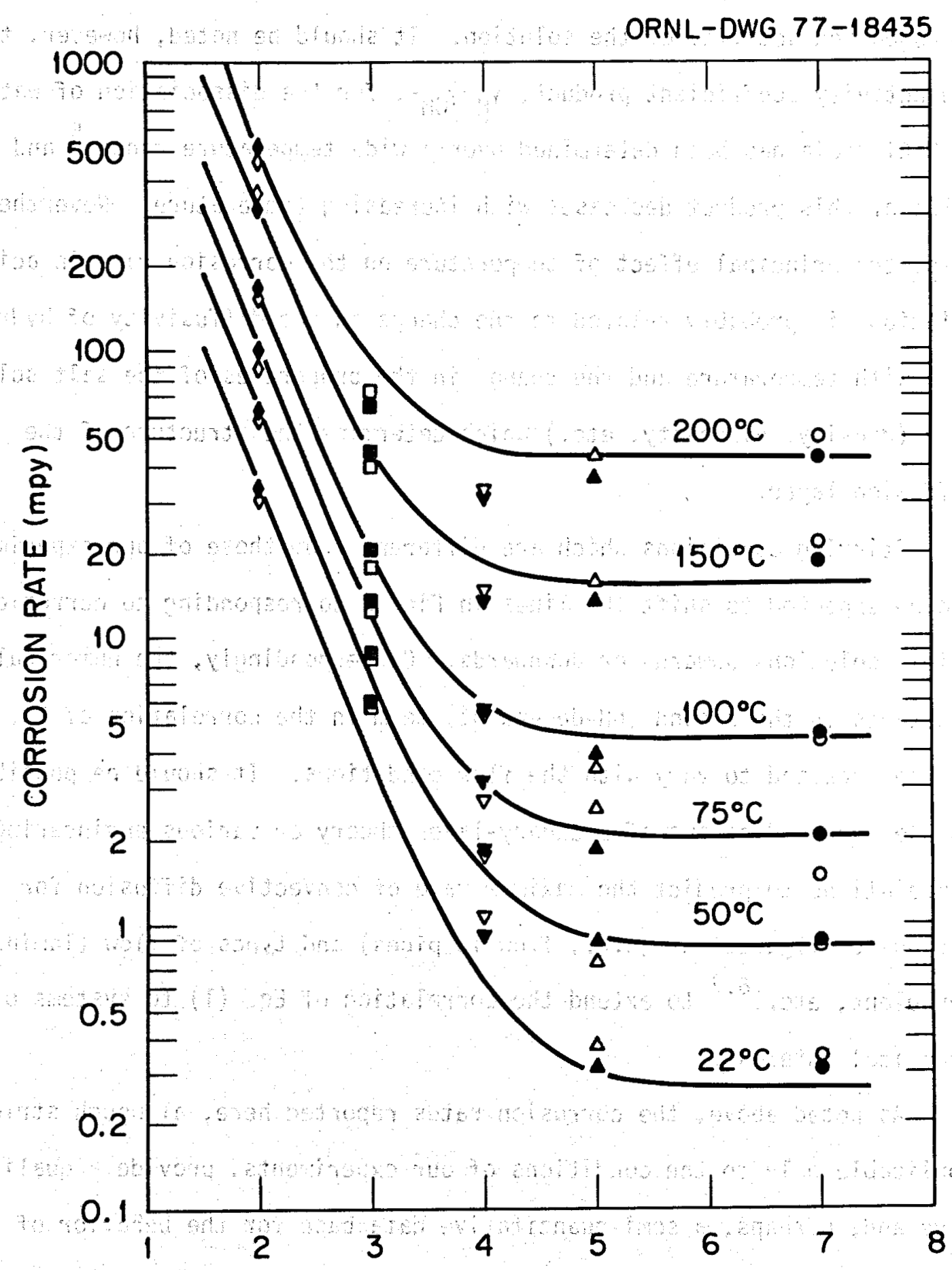

Fig. 3. Variation with $\mathrm{pH}$ of the corrosion rate of A212B carbon steel in $4 \mathrm{M} \mathrm{NaCl}$ as a function of temperature. 
at the lower temperatures) may be due to the effect of temperature on the hydrogen ion activity of the solution. It should be noted, however, that the activity coefficient product, $\gamma_{\mathrm{H}}+\gamma_{\mathrm{OH}^{-}}$, for the dissociation of water in $\mathrm{NaCl}$ media has been determined over a wide temperature range, ${ }^{5}$ and the value of this product decreases with increasing temperature. Nevertheless, the principal effect of temperature on the corrosion rate in acidic solutions is probably related to the change in the diffusivity of hydrogen ions with temperature and the change in the properties of the salt solution (density, viscosity, etc.) which determine the structure of the diffusion layer.

Stirring conditions which are different from those of our experiments can be expected to shift the lines in Fig. 2 corresponding to corrosion in acidic solutions upwards or downwards. Correspondingly, the numerical constants in the second ( $\mathrm{pH}$-dependent) term in the correlation of Eq. (1) can be expected to vary with the flow conditions. It should be possible to use the predictions of boundary-layer theory or various engineering correlations to predict the maximum rate of convective diffusion for various configurations (e.g., flow in pipes) and types of flow (laminar, turbulent, etc. $)^{6,7}$ to extend the correlation of Eq. (1) to systems of practical interest.

As noted above, the corrosion rates reported here, al though strictly applicable only to the conditions of our experiments, provide a qualitative and, perhaps, a semi-quantitative data base for the behavior of iron and carbon steel in deaerated strong brine solutions as a function of $\mathrm{pH}$ and temperature. Some previous measurements, ${ }^{2}$ carried out in $\mathrm{pH} 5$ solutions at $25^{\circ} \mathrm{C}$, showed that chloride ion concentration exerts a significant effect on the corrosion rate of carbon steel. Increasing the 
chloride ion concentration causes a decrease in the spontaneous corrosion rate of carbon steel in strong brine solutions, probably because adsorption of chloride ions on the electrode surface displaces reaction intermediates of the iron-dissolution and hydrogen-evolution reactions from the corroding surface, thereby altering the rates of the interfacial reactions. Mechanistic details of this effect have not been investigated systematically, and obviously further research into the mechanism of the effect of chloride ions on the partial processes of iron corrosion would be appropriate, considering the ubiquity of both ferrous materials and chloride-related corrosion problems. Thus, additional measurements would be required before a correlation similar to Eq. (1) could be developed which is valid over a wide range of chloride ion concentrations. In addition, the presence of other substances (carbonates, sulfides, etc.) which are well-known components of natural brines can be expected to alter drastically the corrosion behavior of the iron - brine system, as exemplified by the data in Fig. 2. The study of such effects is a logical extension of the present type of investigation, and would undoubtedly contribute significantly to the understanding of the principal factors which control corrosion under geothermal conditions.

\section{INFLUENCE OF TEMPERATURE ON PITTING OF}

TYPES 304 AND 316 STAINLESS STEEL IN 4 M NaCl

Austenitic stainless steels, especially those of the 300 series $18 \%$ $\mathrm{Cr}-8 \%$ Ni steels, have been used successfully for some geothermal applications, particularly in steam condensate systems in which temperatures and chloride ion concentrations are relative low. ${ }^{8}$ However, use of these materials has led to failures in a number of geothermal applications, in 
which deaerated strong brines at elevated temperatures are encountered, in contrast to some successful applications in sea-water desalination practice. In addition to the well-known tendency of stainless steel to undergo stress-corrosion cracking, it is also subject to pitting attack in chloride media. It is therefore relevant to measure the susceptibility of stainless steel to pitting attack in deaerated strong brines, such as those encountered in certain geothermal applications, over a wide temperature range.

An upper limit exists on the allowable electrode potentials of stainless steel in chloride solutions without risk of catastrophic pitting attack. This limit is known as the pitting potential. During this period we have carried out measurements of the spontaneous corrosion potentials and the pitting potentials of types 304 and 316 stainless steel in deaerated $4 \underline{M ~ N a C l}$ at $\mathrm{pH}=5$ (measured at room temperature) over the temperature range from $25^{\circ}$ to at least $200^{\circ} \mathrm{C}$. The measurements made use of the galvanostatic method with constant applied anodic current. Following establishment of a steady-state spontaneous corrosion potential, a constant anodic current was applied to the electrode and the transient behavior of the electrode potential was observed. During the early stages of the galvanostatic transient, anodization of the passive oxide layer takes place with increase in the film thickness (at approximately constant field strength within the oxide layer) until penetration of the film by chloride ions and formation of a pit. Upon formation of pits the electrode potential falls more or less rapidly and is subsequently determined by the pit growth process. The electrode potential finally stablizes at a value which is taken to be the pitting potential. Essentially the same final electrode potential is established by the specimen 
regardless of the magnitude of the applied anodic current over wide limits. The pitting potential signifies the electrode potential which must not be approached very closely or exceeded in the medium in question without the occurrence of pitting attack and resultant catastrophic metal wastage. Further, there is evidence to suggest that formation of pits provides sites for stress intensification and thus may act as a precursor of stress-corrosion cracking in certain circumstances.

Figure 4 shows experimental values of the corrosion potentials and the pitting potentials of types 304 and 316 stainless steel in deaerated $4 \underline{\mathrm{M} \mathrm{NaCl}}$ at $\mathrm{pH}=5$ over $\mathrm{a}$ wide temperature range. For comparison, earlier measurements ${ }^{9}$ on type 304 stainless steel in $0.1 \mathrm{M} \mathrm{NaCl}$ solution from $25^{\circ}$ to $50^{\circ} \mathrm{C}$ indicated a pitting potential of approximately $+0.1 \mathrm{~V}$ vs. SCE. Thus, stainless steel pits at significantly lower potentials in strong brine than in weaker chloride solutions. From Fig. 4 it may be seen that, from $25^{\circ}$ up to approximately $175^{\circ} \mathrm{C}$, the pitting potential of type 304 stainless steel was observed to be only approximately $75-100 \mathrm{mV}$ more noble than the spontaneous corrosion potential, even though both potentials decreased by about $150 \mathrm{mV}$ over this temperature region. Further increase in temperature caused the corrosion potential to become more negative, while the pitting potential became more positive. Results obtained with type 316 stainless steel were similar to those observed with type 304 stainless steel, al though pits were much more difficult to initiate on the (molybdenum-containing) type 316 steel, and the pit morphology was qualitatively different. Pits on the type 304 steel were open and sharp-edged, with no significant precipitation of corrosion products within the pits and with substantial polishing of interior surfaces. In contrast, pits on the type 316 steel were filled with a 


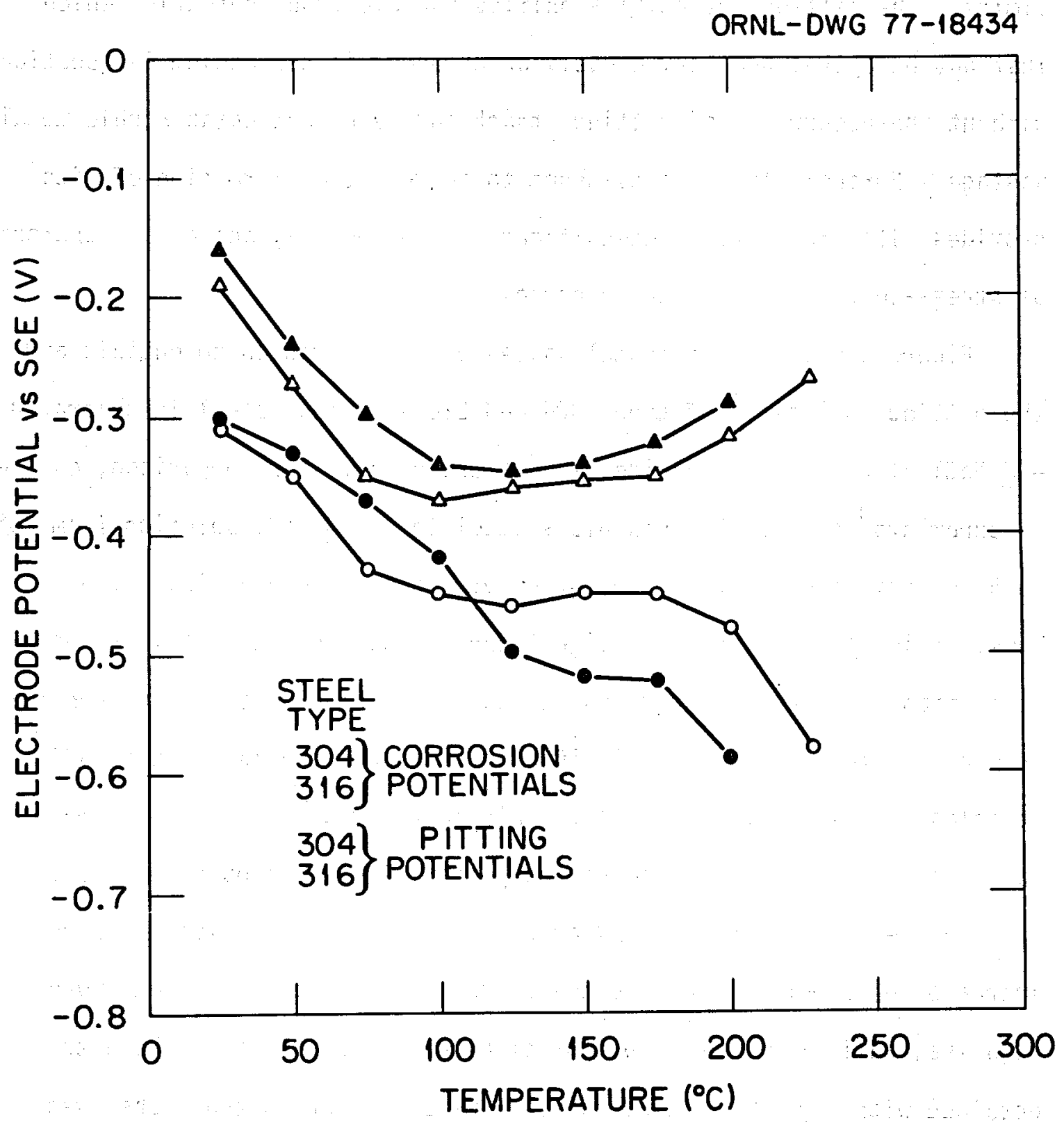

Fig. 4. Pitting potentials and corrosion potentials of types 304 and 316 stainless steel in $4 \mathrm{M} \mathrm{NaCl}$ as a function of temperature. 
porous black corrosion product which, however, conformed well to the original surface of the metal in contact with the electrolyte. The pitting potentials of type 316 were $10-20 \mathrm{mV}$ more noble than those of type 304 over the whole temperature range. These results suggest that, al though stainless steel corrodes spontaneously at an extremely low rate (fractions of a mil per year) in deaerated brine, traces of oxidizing agents could suffice to raise the electrode potential to the pitting potential, resulting in rapid corrosion and penetration. On the other hand, because the difference between the pitting potential and the corrosion potential increases substantially at elevated temperatures (above $100^{\circ} \mathrm{C}$ ), while the spontaneous corrosion rate also increases with temperature, stainless steel may actually be somewhat less susceptible to the influence of oxidizing agents (at a given concentration level) at high temperatures than at low temperatures. Nevertheless, it is evident that use of stainless steel as a material of construction, even in rigorously deaerated brines of controlled composition, is dangerous because of its borderline stability with respect to localized attack.

\section{RESEARCH PLANS FOR THE FORTHCOMING PERIOD}

The work during the remaining three months of the funding period will conclude the studies on corrosivity of geothermal brines which have been carried out by members of the ORNL Chemistry Division in collaboration with personnel of the Metals and Ceramics Division under sponsorship by ERDA's Division of Geothermal Energy. We expect to obtain some additional data on the effect of brine concentration on the corrosion rate of carbon steel from room temperature up to $200^{\circ} \mathrm{C}$. These measurements, which will be carried out in $2 \underline{\mathrm{M}}, 0.5 \mathrm{M}$, and $0.1 \mathrm{M} \mathrm{NaCl}$, will extend the results of our 
previous measurements in $4 \mathrm{M} \mathrm{NaCl}$ to more dilute solutions, so that hopefully quantitative data may be available over a sal inity range commonly encountered in geothermal applications. Following the completion of the measurements, a final report will be prepared which comments on prior work on electrochemical aspects of the corrosion of iron and carbon steel in chloride solutions and summarizes the results of these, investigations. 


\section{REFERENCES}

1. F. A. Posey and A. A. Palko, Corrosivity of Geothermal Brines Progress Report for Period Ending June 1976, ORNL/TM-5688 (December 1976).

2. F. A. Posey, A. A. Palko, and A. L. Bacarella, Corrosivity of Geothermal Brines Progress Report for Period Ending December 1976, ORNL/TM-5863 (Apri1 1977).

3. E. Heitz and W. Schwenk, Brit. Corros. J. 11, 74 (1976).

4. L. M. Callow, J. A. Richardson, and J. L. Dawson, Brit. Corros, J. 11, 123, 132 (1976).

5. R. H. Busey and R. E. Mesmer, J. Solution Chem. $\underline{5}, 147$ (1976).

6. H. Schlichting, Boundary-Layer Theory, 6th ed., McGraw-Hill, New York, N. Y., 1968.

7. J. Newman, Electrochemical Systems, Prentice-Hall, Englewood $\mathrm{Cl}$ iffs, N. J., 1973.

8. D. W. Shannon, Economic Impact of Corrosion and Scaling Problems in Geothermal Energy Systems, BNWL-1866 (January 1975).

9. H. P. Leckie and H. H. Uhlig, J. Electrochem. Soc. 113, 1262 (1966). 


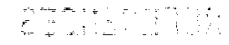

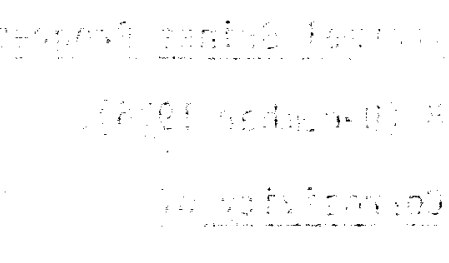

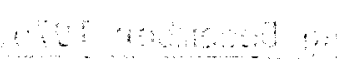
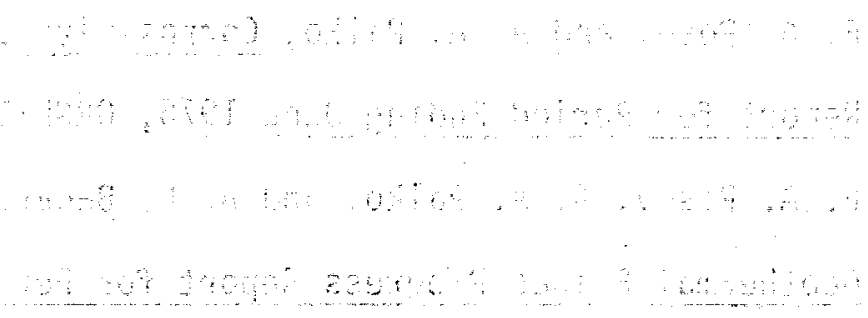

a.

a

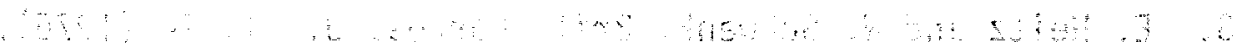

$+2-2+2$

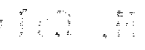

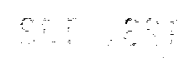

$\therefore$

$3+1+2=$

$\therefore \quad \therefore$

$\because \cdots+\cdots$

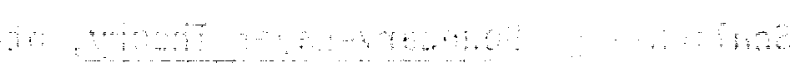

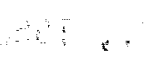

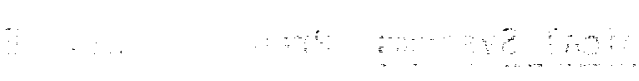

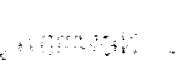


ORNL/TM-6159

Dist. Category UC-4

\section{INTERNAL DISTRIBUTION}

1. A. L. Bacarella
2. J. Bievins, ORO
3. E. G. Bohlmann
4. J. H. DeVan
5. L. M. Ferris
6. J. C. Griess
7. O. L. Keller
8. E. J. Kelly
9. R. N. Lyon
10. R. E. Mesmer
11. R. E. Meyer
12. J. W. Michel
13. A. A. Palko
14-33. F. A. Posey
34. H. Postma
35. M. W. Rosenthal
36. G. M. Slaughter
37. I. L. Thomas
38. J. R. Weir
39. A. Zucker
40-41. Central Research Library
42. ORNL Patent Office
43. ORNL Y-12 Technical Library, Document Reference Department
44. Laboratory Records, ORNL, RC
45-46. Laboratory Records Department

\section{EXTERNAL DISTRIBUTION}

47. Director of Research and Technical Support Division, DOE-ORO

48. M. J. Danielson, Battelle Pacific Northwest Laboratories, Battelle Blvd., Richland, WA 99352

49. R. P. Epple, Division of Physical Research, DOE, Washington, DC 20545

50. A. Goldberg, Lawrence Livermore Laboratory, P. 0. Box 808, Livermore, CA 94550

51. J. E. Harrar, Lawrence Livermore Laboratory, P. 0. Box 808, Livermore, CA 94550

52. G. A. Kolstad, Division of Physical Research, DOE, Washington, DC 20545

53. R. D. McCright, Lawrence Livermore Laboratory, P. 0. Box 808, Livermore, CA 94550

54. D. E. Michels, Aerojet Nuclear Co., 550 Second St., Idaho Falls, ID 83401

55. P. B. Needham, Bureau of Mines, U. S. Dept. of Interior, College Park, MD 20740

56. H. H. Paalman, Research Laboratories, Dow Chemical U.S.A., 2800 Mitchell Drive, Wainut Creek, CA 94598

57-61. R. R. Reeber, Division of Geothermal Energy, DOE, 20 Massachusetts Ave., Washington, DC 20545

62. M. A. Selim, Core Laboratories, Inc., P. 0. Box 47547, Dallas, TX 75247

63. D. W. Shannon, Battelle Pacific Northwest Laboratories, Battelle Blvd., Richland, WA 99352

64. B. C. Syrett, Stanford Research Institute, Ravenswood Ave., Menlo Park, CA 94025

65. R. Tallman, E. G. \& G. Idaho, Inc., P. 0. Box 1625, Idaho Falls, ID 83401

66-250. Given distribution per TID 4500, Chemistry Category UC-4 (25 copies, NTIS) 